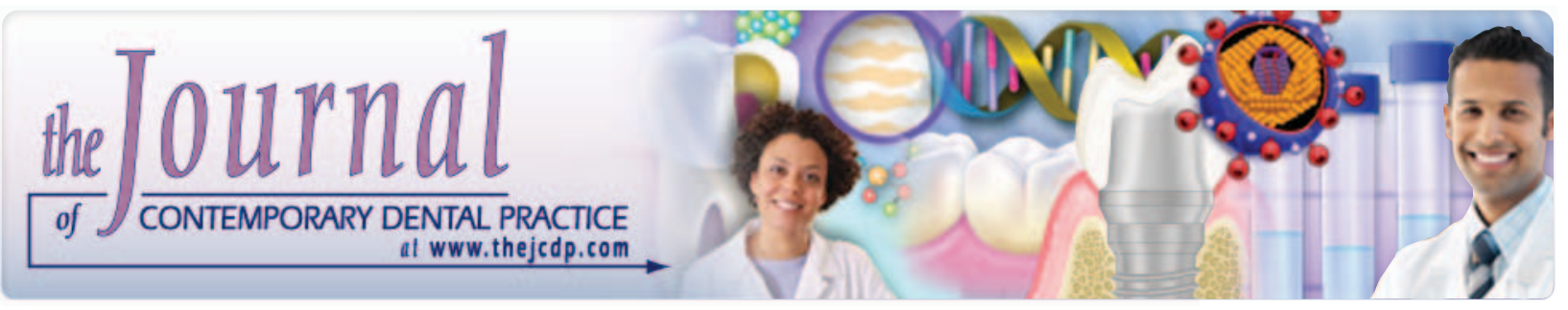

\title{
Effectiveness of Procedures for the Chemical-Mechanical Control of Dental Biofilm in Orthodontic Patients
}

Karla Magalhães Alves, DDS, MSc; Daniela Goursand, DDS, MSc; Elton Gonçalves Zenobio, DDS, MSc, PhD; Roberval Almeida Cruz, DDS, MSc, PhD

\begin{abstract}
Aim: Assess the effectiveness of chemicalmechanical control associated with orientation and motivation for the control of dental biofilm in orthodontic patients.

Methods and Materials: Thirty patients between 12 and 21 years of age wearing a fixed orthodontic appliance were divided into three groups. The control group (G1) received orientation regarding oral hygiene. The experimental groups (G2 and $\mathrm{G} 3$ ) received orientation regarding oral hygiene and diet as well as a hygiene kit and mouthwash; the mouthwash given to G2 was a placebo and that given to G3 contained essential oils (Listerine ${ }^{\circledR}$ ).
\end{abstract}

Results: In the comparison between T0 and T60, vestibular gingivitis was worse in $\mathrm{G} 1(p<0.05)$, with no statistically significant differences regarding lingual gingivitis and biofilm. G2 and G3 exhibited a significant improvement in clinical conditions. In the comparison between groups, G3 had undergone a significantly greater improvement than the other groups.

Conclusion: The use of the commercial mouthwash, together with mechanical oral hygiene, orientation, and motivation, proved to be adequate conduct for the maintenance of oral health in orthodontic patients.

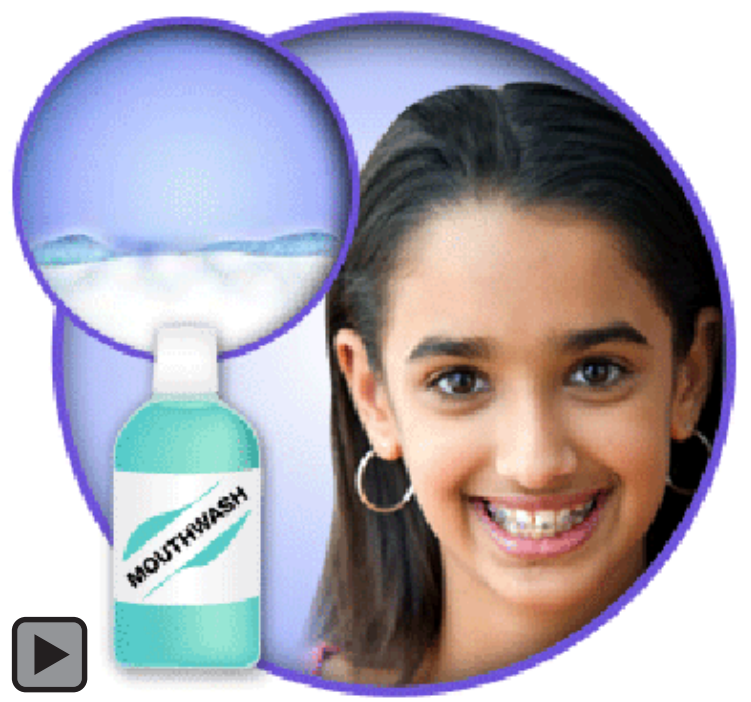

Clinical Significance: The present study contributes toward the maintenance of oral health in patients who wear a fixed orthodontic appliance through the prevention of dental biofilm buildup.

Keywords: Randomized experimental study, biofilm, prevention and control, orthodontics.

Citation: Alves KM, Goursand D, Zenobio EG, Cruz RA. Effectiveness of Procedures for the Chemical-Mechanical Control of Dental Biofilm in Orthodontic Patients. J Contemp Dent Pract [Internet]. 2010 March; 11(2):041-048. Available from: http://www.thejcdp.com/journal/view/ volume11-issue2-alves. 


\section{Introduction}

Orthodontics is a dental specialty for the prevention, interception, and correction of dental and skeletal abnormalities by correcting the positioning of the teeth. However, orthodontic appliances hamper oral hygiene and contribute toward an additional build up of biofilm, which may lead to demineralization of the enamel and gingivitis. ${ }^{1-3}$ A number of studies have stressed the association between fixed orthodontic appliances and an increased buildup of biofilm. $\frac{1-8}{}$ Biofilm has a significant impact on the incidence of caries and periodontal disease. ${ }^{9}$ When there is build up of biofilm during orthodontic treatment, its pathogenicity increases. Thus, patients need to be submitted to a hygiene program for the maintenance of oral health. ${ }^{1,4,10,11}$ Prior to treatment, orthodontic patients should be made aware of problems stemming from inadequate oral hygiene, as they will be at risk for caries and periodontal disease. Motivation and hygiene control should be stressed and monitored by the orthodontist, who should not transfer this responsibility to the patient or a general practitioner. ${ }^{12}$

The mechanical removal of biofilm through brushing and the use of dental floss continues to be the most effective method for the prevention of oral disease, but orthodontic patients experience considerable difficulty in achieving an adequate degree of mechanical hygiene..$^{7,12}$ Thus, studies have been carried out to determine alternatives that are capable of avoiding the appearance of

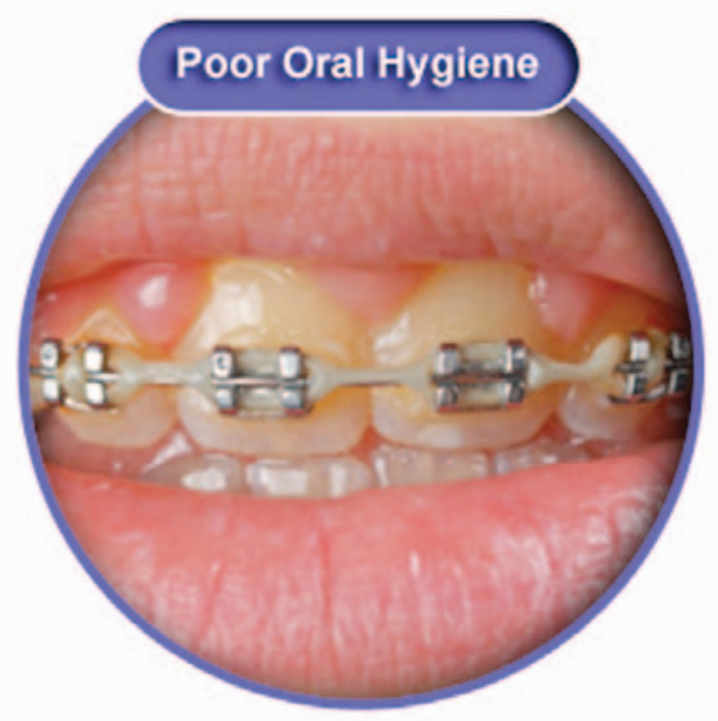

white spots and gingivitis. ${ }^{4.5,7.8,12-14}$ Chlorhexidine is the best known and most effective agent for the chemical control of dental biofilm. However, prolonged use causes undesirable effects, such as stains on the teeth, changes in the taste buds, and a burning sensation in the soft tissues. ${ }^{15-18}$ Therefore, alternative chemical agents have been sought in order to provide positive results with no side effects. Antiseptics containing essential oils have been widely studied and have been found to exhibit satisfactory results in the control of dental biofilm. ${ }^{17,19-26}$ Chemical control through the use of a mouthwash containing essential oils allows a reduction in biofilm and may be employed as an auxiliary method of oral hygiene. $\frac{17,18}{}$

The aim of the present study was to assess the effectiveness of chemical-mechanical control procedures for in-home use, associated with conventional oral hygiene care, instruction, and motivation, for the control of dental biofilm in patients who wear a fixed dental appliance.

\section{Methods and Materials}

\section{Study Design}

The researcher was trained and calibrated for the assessment and determination of dental and gingival biofilm indices. For the calibration exercise, 12 patients were examined and reexamined after an interval of seven days. Diagnostic agreement was assessed using the kappa coefficient, which achieved a value of 0.8 and was therefore considered good.

The main investigation was a double-blind longitudinal study on a convenience sample made up of 30 patients ( 10 male and 20 female) between 12 and 21 years of age. The sample was randomized by age and comprised patients awaiting dental care at the clinics. All patients wore a fixed orthodontic appliance and were under care at the Orthodontic Clinic of the Dental School of the Pontifícia Universidade Católica de Minas Gerais (Brazil). The project received approval from the Ethics Committee of the University (CAAE - 0108.0.213.000-07). The patients and/or their guardians signed terms of informed consent, thereby agreeing to participate in the experiment.

The patients were examined in a dental chair with the aid of artificial light from the reflector. The 
following materials were used for the exam: dental mirror, no. 5 exploratory probe, and a millimeter periodontal probe (PC 15 Trinity $^{\circledR}$, São Paulo, SP, Brazil). The results of the indices were annotated on a follow-up chart.

The participants were divided into three groups of 10: one control group and two experimental groups. The control group (Group 1, G1) only received the routine orientation normally given to all patients at the orthodontic clinic. The patients in G1 were examined for the quantification of dental and gingival biofilm indices at the beginning of the study (T0) and after a period of 60 days (T60).

All the patients in the experimental groups, together with their parents/guardians, were invited to participate in a lecture, at which they received information regarding the study and instructions on diet, oral hygiene, and how they should procee d during the observational period. Photos were shown demonstrating the possible consequences of inadequate oral hygiene, such as stained teeth, caries, and gingivitis. For the oral hygiene instruction, a dummy fixed with orthodontic braces (Modelos Ortodônticos ROIC, Três Corações, MG, Brazil) was used, employing Ortodôntica $^{\mathrm{TM}}$ and Interdental ${ }^{\mathrm{TM}}$ brushes (Oral- ${ }^{\circledR}{ }^{\circledR}$, Procter \& Gamble, Naucalpan, Mexico) and Super Floss $^{\circledR}$ dental floss (Oral-B ${ }^{\circledR}$, Procter \& Gamble, Newbridge, Ireland). The regions of the greatest buildup of dental biofilm were shown, along with a demonstration of how to clean these sites in order to avoid damage to the oral tissues. The initial oral examination was performed on this same day (TO) for the determination of dental and gingival biofilm indices. All teeth in both arches (from the first permanent molar on one side to the other) were examined. All data were collected by a single examiner. The patients then received hygiene kits containing Ortodôntica ${ }^{\mathrm{TM}}$ and Interdental ${ }^{\mathrm{TM}}$ brushes, Superfloss ${ }^{\mathrm{TM}}$ dental floss, mouthwash, and written instructions (a pamphlet with instructions on cleaning teeth while wearing a fixed orthodontic appliance).

The patients undergoing intervention were divided into two groups. Group 2 (G2) received a placebo mouthwash (distilled water with mint aroma and green dye). Group 3 (G3) received mouthwash containing essential oils (Listerine ${ }^{\circledR}$, Johnson \& Johnson, Guarulhos, SP, Brazil). The products were placed in coded receptacles and the codes were not shown to the examiner. Both groups were instructed to gargle $20 \mathrm{ml}$ for 30 seconds twice a day. ${ }^{17.22}$ They also were instructed to use the dental floss after meals and brush at least three times a day throughout the observation period.

The brushing technique employed was vibratory, as applied by Neves and Cruz, ${ }^{8}$ and included the use of the Interdental brush. After 30 days, the patients in the experimental groups returned for further motivation. The condition of the brushes was examined and more dental floss was given, but the biofilm indices were not determined at this time. At 60 days from the beginning of the study, the patients returned for the final evaluation and determination of biofilm indices.

For the determination of biofilm indices, visible plaque was assessed using the method described by Silness and Löe. ${ }^{\underline{27}}$ After adequate drying, the vestibular surfaces of all the teeth in the upper and lower arches (from the first permanent molar on one side to the other) were examined with a probe along the entire tooth to the entrance of the gingival pocket. The following rating scale was used: $0=$ absence of biofilm; $1=$ visible biofilm on the tip of the probe but not visible to the naked eye; 2 = biofilm visible to the naked eye (layer with fine to moderate thickness); $3=$ thick biofilm, with soft tissue buildup. The gingival index was that established by Lö $e^{9,28}$ and was determined for the vestibular and lingual surfaces following probing of the gingival pocket. A grade corresponding to the index was attributed to each surface: Grade 0 = normal gums; Grade 1 = mild inflammation, slight change in color, edema, absence of bleeding; Grade 2 = moderate inflammation, redness, edema, smooth, shiny surface, bleeding upon probing; Grade 3 = severe inflammation, accentuated redness, edema, ulceration, tendency toward spontaneous bleeding. After collecting the data, the individuals were classified as having mild gingivitis (mean gingival index of 0.1 to 1.0 ), moderate gingivitis (mean gingival index of 1.1 to 2.0 ), or severe gingivitis (mean gingival index of 2.1 to 3.0). The data were recorded and tabulated.

\section{Statistical Analysis}

Statistical analysis was carried out using the SPSS version 15.0 program (SPSS Inc., Chicago, Illinois, USA). Median values were determined for the dental and gingival biofilm indices of each patient at the beginning and end of the 
experiment. Descriptive analysis was performed for each participant and the clinical conditions of each group. Kruskal-Wallis was performed to determine whether the three groups were similar (nonparametric sample). The Wilcoxon test was used to assess improvement in clinical condition within the same group between the two evaluation times (T0 and T60). Differences between groups regarding biofilm indices were determined using the Tamhane post hoc test, as no equality of variance was found between groups.

\section{Results}

The mean age of the participants was 15.4 years (median $=15.0) ; 67 \%$ of the sample were female and $33 \%$ were male. The Kruskal-Wallis test was performed for the comparison of the three groups (Table 1). There were significant differences between groups with regard to initial and final dental and gingival biofilm indices $(p<0.05)$.

The Wilcoxon test revealed differences between the beginning and end of the experiment in each group (Table 2). In the control group (G1), there was an increase in vestibular gingivitis between T0 and T60 $(p=0.02)$. There was also a slight increase in lingual gingivitis, but this difference did not achieve statistical significance $(p=0.26)$. Mean and median dental biofilm values were 1.74 and 2.00 , respectively, at T0, whereas these values were 1.68 and 1.96, respectively, at T60; this difference also did not achieve statistical significance $(p=0.61)$. In $\mathrm{G} 2$, there was an improvement in vestibular $(p=0.01)$ and lingual $(p=0.03)$ gingivitis. Mean and median biofilm values at T0 were 1.80 and 2.00 , respectively, whereas these values were 0.71 and 0.67 , respectively, at T60, thereby demonstrating a statistically significant difference $(p=0.01)$. In group G3, there was an improvement in vestibular $(p=0.02)$ and lingual $(p=0.02)$ gingivitis. Mean and median biofilm values at T0 were 1.91 and 2.00, respectively, whereas these values were 0.63 and 0.49 , respectively, at $\mathrm{T} 60$, thereby demonstrating a statistically significant difference $(p=0.00)$.

The Tamhane post hoc test was employed to determine differences between groups (Table 3). There were no significant differences between groups regarding initial vestibular gingivitis $(p>0.05)$. Final vestibular gingivitis obtained a greater reduction in $\mathrm{G} 3$ than $\mathrm{G} 1(p<0.05)$; there was no significant difference regarding final vestibular gingivitis between G2 and G3 $(p>0.05)$. There were no significant differences between groups regarding initial lingual gingivitis $(p>0.05)$. In the comparison of final lingual gingivitis, there were no statistically significant differences between $\mathrm{G} 1$ and $\mathrm{G} 2$ or between $\mathrm{G} 2$ and $\mathrm{G} 3$ ( $p>0.05)$, but there was a statistically significant reduction in $\mathrm{G} 3(p<0.05)$ when compared to $\mathrm{G} 1$. There were no significant differences between groups regarding initial biofilm $(p>0.05)$. There were statistically greater reductions in final biofilm in $\mathrm{G} 2$ and $\mathrm{G} 3$ when compared to $\mathrm{G} 1(p<0.05)$, with no statistically significant difference between G2 and G3 ( $p>0.05)$.

\section{Discussion}

The buildup of biofilm and consequent gingivitis are common events among orthodontic patients due to difficulties in controlling oral hygiene. $\frac{1.3}{}$ Previous studies have demonstrated that orthodontic appliances contribute toward a greater buildup of biofilm and have a negative affect on hygiene..$^{\frac{2.3}{3}}$ The present study corroborates these findings, as the patients exhibited varied degrees of biofilm buildup and gingivitis at the beginning of the study.

Table 1. Discriminant statistics between the three groups studied.*

\begin{tabular}{|l|c|c|c|c|c|c|}
\hline & $\begin{array}{c}\text { Initial } \\
\text { vestibular } \\
\text { gingivitis }\end{array}$ & $\begin{array}{c}\text { Final } \\
\text { vestibular } \\
\text { gingivitis }\end{array}$ & $\begin{array}{c}\text { Initial } \\
\text { lingual } \\
\text { gingivitis }\end{array}$ & $\begin{array}{c}\text { Final } \\
\text { lingual } \\
\text { gingivitis }\end{array}$ & $\begin{array}{c}\text { Initial } \\
\text { biofilm }\end{array}$ & $\begin{array}{c}\text { Final } \\
\text { biofilm }\end{array}$ \\
\hline$p$-value & 0.33 & 0.00 & 0.29 & 0.00 & 0.73 & 0.01 \\
\hline *Kruskal-Wallis test & \multicolumn{7}{|l|}{} \\
\hline
\end{tabular}


Table 2. Discriminant statistics of each clinical group at initial evaluation (TO) and at the end of the experiment (T60).*

\begin{tabular}{|c|c|c|c|c|c|c|c|c|c|}
\hline \multirow[b]{2}{*}{ Participant } & \multirow[b]{2}{*}{ Group } & \multicolumn{4}{|c|}{ Initial evaluation: TO } & \multicolumn{4}{|c|}{ Final evaluation: T60 } \\
\hline & & $\begin{array}{c}\text { Mean } \\
\text { vestibular } \\
\text { gingivitis }\end{array}$ & $\begin{array}{c}\text { Mean } \\
\text { lingual } \\
\text { gingivitis }\end{array}$ & $\begin{array}{c}\text { Mean } \\
\text { biofilm }\end{array}$ & $\begin{array}{c}\text { Meadian } \\
\text { biofilm }\end{array}$ & $\begin{array}{c}\text { Mean } \\
\text { vestibular } \\
\text { gingivitis }\end{array}$ & $\begin{array}{c}\text { Mean } \\
\text { lingual } \\
\text { gingivitis }\end{array}$ & $\begin{array}{c}\text { Mean } \\
\text { biofilm }\end{array}$ & $\begin{array}{c}\text { Meadian } \\
\text { biofilm }\end{array}$ \\
\hline 1 & G1 & 1.56 & 1.62 & 2.00 & 2.00 & 1.50 & 1.25 & 1.81 & 2.00 \\
\hline 2 & G1 & 1.60 & 1.40 & 2.05 & 2.00 & 1.85 & 1.40 & 2.00 & 2.00 \\
\hline 3 & G1 & 1.50 & 1.50 & 1.00 & 1.00 & 1.50 & 1.00 & 1.25 & 1.00 \\
\hline 4 & G1 & 1.46 & 1.16 & 2.00 & 2.00 & 1.67 & 1.33 & 2.00 & 2.00 \\
\hline 5 & G1 & 1.00 & 1.00 & 1.00 & 1.00 & 1.04 & 1.00 & 0.00 & 0.00 \\
\hline 6 & G1 & 1.38 & 0.50 & 2.00 & 2.00 & 1.75 & 1.50 & 1.80 & 2.00 \\
\hline 7 & G1 & 1.20 & 0.80 & 2.16 & 2.00 & 1.62 & 1.58 & 1.92 & 2.00 \\
\hline 8 & G1 & 1.42 & 1.10 & 1.17 & 1.00 & 1.67 & 1.67 & 2.00 & 2.00 \\
\hline 9 & G1 & 1.86 & 1.67 & 2.00 & 2.00 & 2.05 & 1.57 & 2.00 & 2.00 \\
\hline 10 & G1 & 1.67 & 1.13 & 2.00 & 2.00 & 1.71 & 1.42 & 2.00 & 2.00 \\
\hline 11 & G2 & 1.63 & 1.17 & 1.67 & 2.00 & 1.38 & 0.00 & 2.00 & 2.00 \\
\hline 12 & G2 & 1.34 & 1.42 & 2.00 & 2.00 & 1.25 & 1.34 & 1.00 & 1.00 \\
\hline 13 & G2 & 1.75 & 1.42 & 2.00 & 2.00 & 1.25 & 1.46 & 1.04 & 1.00 \\
\hline 14 & G2 & 1.60 & 1.20 & 2.00 & 2.00 & 1.10 & 1.30 & 0.00 & 0.00 \\
\hline 15 & G2 & 1.94 & 1.94 & 2.00 & 2.00 & 1.00 & 0.94 & 0.00 & 0.00 \\
\hline 16 & G2 & 1.34 & 1.25 & 1.67 & 2.00 & 1.00 & 0.00 & 0.00 & 0.00 \\
\hline 17 & G2 & 2.00 & 2.00 & 2.00 & 2.00 & 2.00 & 2.00 & 0.00 & 0.00 \\
\hline 18 & G2 & 2.00 & 1.95 & 1.68 & 2.00 & 1.27 & 1.45 & 1.00 & 1.00 \\
\hline 19 & G2 & 1.25 & 0.75 & 1.00 & 1.00 & 1.17 & 0.08 & 0.33 & 0.00 \\
\hline 20 & G2 & 1.75 & 1.75 & 2.00 & 2.00 & 1.67 & 1.62 & 1.75 & 2.00 \\
\hline 21 & G3 & 0.92 & 0.50 & 2.00 & 2.00 & 1.38 & 1.17 & 1.00 & 1.00 \\
\hline 22 & G3 & 1.82 & 0.90 & 2.95 & 2.00 & 0.32 & 0.00 & 1.00 & 1.00 \\
\hline 23 & G3 & 1.61 & 1.61 & 1.04 & 1.00 & 0.52 & 0.48 & 0.30 & 0.00 \\
\hline 24 & G3 & 1.95 & 2.00 & 2.00 & 2.00 & 0.95 & 0.60 & 0.75 & 1.00 \\
\hline 25 & G3 & 2.10 & 2.00 & 2.15 & 2.00 & 0.90 & 0.00 & 2.00 & 2.00 \\
\hline 26 & G3 & 1.50 & 1.36 & 1.82 & 2.00 & 1.09 & 0.00 & 0.64 & 1.00 \\
\hline 27 & G3 & 1.84 & 1.63 & 2.17 & 2.00 & 0.88 & 1.00 & 0.00 & 0.00 \\
\hline 28 & G3 & 1.30 & 0.50 & 1.58 & 2.00 & 1.13 & 1.13 & 0.33 & 0.00 \\
\hline 29 & G3 & 1.34 & 1.50 & 2.00 & 2.00 & 1.08 & 0.00 & 0.25 & 0.00 \\
\hline 30 & G3 & 1.66 & 1.58 & 1.42 & 2.00 & 0.46 & 0.58 & 0.00 & 0.00 \\
\hline
\end{tabular}

Evidence from clinical trials has demonstrated that oral health status is significantly improved when adding an antimicrobial mouthwash to the oral hygiene routine in comparison to brushing and flossing alone. ${ }^{15,19,26,29}$ Thus, the antiseptic mouthwash Listerine ${ }^{\circledR}$ was used in the present study in order to improve the oral health status of orthodontic patients, as this product was developed in order to provide antimicrobial activity. When associated with the mechanical control of dental biofilm, the aim of this mouthwash is to inhibit the development of biofilm and consequent gingivitis. As it has no side effects, this mouthwash may be used on a daily basis. ${ }^{13,17,22,29,30}$

The effects of gargling with this mouthwash were assessed in the present study by comparing it with a placebo solution and a control group (with no mouthwash) — both also associated with the mechanical removal of dental biofilm-for a period of 60 days. The group using the commercial mouthwash (G3) achieved a significant reduction in biofilm and gingivitis in comparison to the initial indices. These findings are in agreement with other studies that have demonstrated the 
Table 3. Tamhane post hoc test to determine differences between groups.

\begin{tabular}{|c|c|c|c|}
\hline Clinical Conditions & Groups compared & $\begin{array}{c}\text { Value of test } \\
\text { (p-value) }\end{array}$ & $95 \% \mathrm{Cl}$ \\
\hline \multirow{3}{*}{ Initial vestibular gingivitis } & Control x Placebo & $-0.19(0.30)$ & -0.50 to 0.11 \\
\hline & Control x Listerine ${ }^{\circledR}$ & $-0.14(0.68)$ & -0.49 to 0.22 \\
\hline & Placebo $x$ Listerine ${ }^{\circledR}$ & $-0.06(0.97)$ & -0.32 to 0.43 \\
\hline \multirow{3}{*}{ Final vestibular gingivitis } & Control x Placebo & $-0.33(0.06)$ & -0.01 to 0.67 \\
\hline & Control x Listerine ${ }^{\circledR}$ & $0.76^{*}(0.00)$ & 0.41 to 1.12 \\
\hline & Placebo x Listerine $^{\circledR}$ & $0.44^{*}(0.02)$ & 0.55 to 0.82 \\
\hline \multirow{3}{*}{ Initial lingual gingivitis } & Control x Placebo & $-0.30(0.30)$ & -0.76 to 0.16 \\
\hline & Control x Listerine ${ }^{\circledR}$ & $-0.17(0.81)$ & -0.73 to 0.39 \\
\hline & Placebo x Listerine ${ }^{\circledR}$ & $0.13(0.92)$ & -0.45 to 0.70 \\
\hline \multirow{3}{*}{ Final lingual gingivitis } & Control x Placebo & $0.35(0.44)$ & -0.33 to 1.04 \\
\hline & Control x Listerine ${ }^{\circledR}$ & $-0.88^{*}(0.00)$ & 0.41 to 1.34 \\
\hline & Placebo x Listerine $^{\circledR}$ & $0.52(0.22)$ & -0.22 to 1.27 \\
\hline \multirow{3}{*}{ Initial biofilm } & Control x Placebo & $-0.06(0.98)$ & -0.55 to 0.42 \\
\hline & Control x Listerine ${ }^{\circledR}$ & $-0.17(0.82)$ & -0.75 to 0.40 \\
\hline & Placebo $x$ Listerine ${ }^{\circledR}$ & $-0.11(0.92)$ & -0.62 to 0.40 \\
\hline \multirow{3}{*}{ Final biofilm } & Control x Placebo & $0.97^{*}(0.02)$ & 0.14 to 1.79 \\
\hline & Control x Listerine ${ }^{\circledR}$ & $1.05^{*}(0.00)$ & 0.32 to 1.78 \\
\hline & Placebo x Listerine $^{\circledR}$ & $0.08(0.99)$ & -0.73 to 0.90 \\
\hline \multicolumn{4}{|c|}{${ }^{*}$ The difference is significant at 0.05} \\
\hline
\end{tabular}

effectiveness of mouthwashes containing essential oils for the control of biofilm and gingivitis. ${ }^{19,20,22,23,26}$

There was also a reduction in biofilm and gingivitis in the placebo group (G2), which may be attributed to an increase in knowledge regarding hygiene as well as the motivation and the very fact of gargling twice a day with a mouthwash. The information provided may have motivated the patients to take better care of their teeth. The patients in the control group (G1) demonstrated an increase in gingivitis indices over time, while there was no significant difference in the biofilm index.

The present study also has proven the importance of motivating patients in the control of dental biofilm. ${ }^{2,8}$ Better results regarding biofilm and gingivitis indices were obtained in the experimental groups, regardless of the product used. The instructions and motivation carried out at the beginning of the study as well as after 30 days may have had an influence over the reduction in the amount of biofilm and gingivitis in G2 and

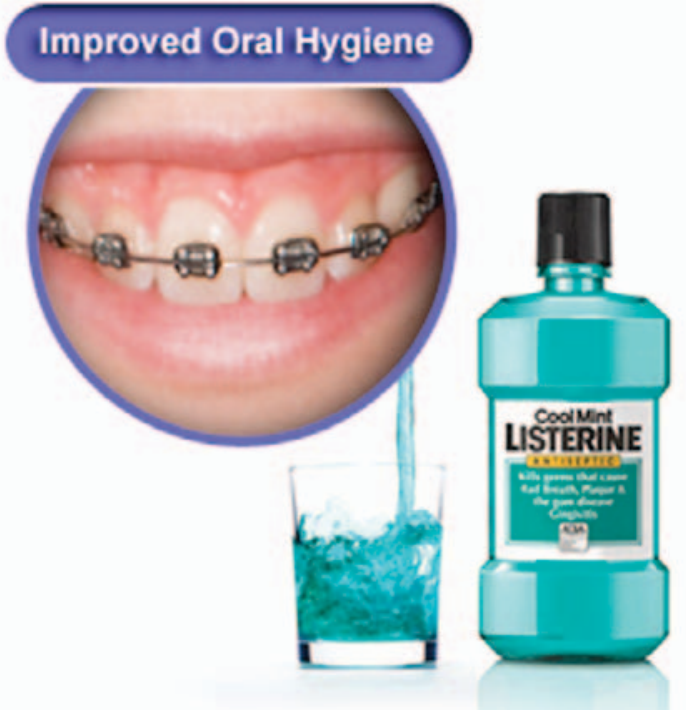


G3 $(p<0.05)$. This suggests the importance of establishing a motivation and orientation program for the mechanical control of biofilm in these patients in order to prevent injury to the soft tissues.

The effectiveness of Listerine ${ }^{\circledast}$ in controlling biofilm and gingivitis has been demonstrated in a number of short-term and long-term controlled clinical

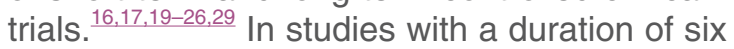
months or more, this mouthwash had been shown to significantly reduce biofilm and gingivitis, which, to some extent, is in agreement with the findings of the present study, in which gingivitis indices were significantly better when using this mouthwash in comparison to the placebo..$^{17,20,22}$

The statistical analysis revealed a significantly greater reduction in gingivitis in G3 when compared to G2, which underlines the antimicrobial effect of the product employed. The commercial mouthwash also achieved a greater reduction in biofilm indices, but these results did not achieve statistical significance. In comparison to G1, G3 achieved significantly greater reductions in both biofilm and gingivitis. In some aspects, these results contradict a previous study, in which the use of Listerine ${ }^{\circledast}$ on orthodontic patients was assessed for a six-month period (the control group did not use a placebo mouthwash); it was suggested that the reduction in indices could have been due to the mechanical effect of the mouthwash and that further studies should be carried out with a negative mouthwash control on orthodontic patients in order to confirm whether the reduction in indices is due to the antimicrobial effect of the commercial mouthwash. Indeed, this was part of the aim of the present study.

Previous studies have found mouthwashes containing chlorhexidine to be more effective than Listerine $^{\circledR}$ in reducing biofilm, but effectiveness with regard to gingivitis has proven comparable. ${ }^{17,25}$ The present study corroborates these findings, as the commercial antiseptic was effective in significantly reducing gingivitis, even without inhibiting the buildup of biofilm, thereby demonstrating the bactericidal effect of Listerine ${ }^{\circledast 21,23}$

\section{Conclusion}

The use of Listerine ${ }^{\circledR}$ twice a day, together with brushing, the use of dental floss, instruction, and motivation, achieved a clinically and statistically significant reduction in biofilm and gingivitis. Thus, for greater oral hygiene control and a reduction in biofilm and gingivitis indices, orthodontists should consider the administration of this mouthwash in routine hygiene for patients. As the patients evaluated had some degree of gingivitis and biofilm at the beginning of the study, a preventive, motivational approach is needed both prior to and throughout orthodontic treatment in order to maintain satisfactory oral health. Thus, a program that includes the protocol described in the present study could be efficient and functional.

\section{Clinical Significance}

The present study contributes toward the maintenance of oral health in patients who wear a fixed orthodontic appliance through the prevention of dental biofilm buildup.

\section{References}

1. Balenseifen JW, Madonia JV. Study of dental plaque in orthodontic patients. J Dent Res. 1970; 49(2):320-4.

2. Icaza JE, Pinzan A, Campos A Jr, Freitas MR. Avaliação comparativa do controle de placa bacteriana e da gengivite em pacientes sob tratamento ortodôntico, sem orientação, e com métodos de higiene supervisionados e de controle profissional. Ortodontia. 1988; 22(3):29-39.

3. Uetanabaro T, Martins JES, Andrade JLF. Acúmulo de placa bacteriana em pacientes portadores de colagem direta e anéis convencionais [Plaque accumulation in patients with direct bonding and conventional rings]. Rev Gaúch Odontol. 1984; 32(2):161-6.

4. Carvalho LS, Lascala NT. Estudo em pacientes portadores de aparelho ortodôntico, correlacionando os índices de placa e gengival, à escovação dental, e com bochechos de fluoreto de sódio, e com Cepacol ${ }^{\circledR}$ [Plaque and gingival index in orthodontic patients undergoing toothbrushing and mouthrinses with sodium fluoride and Cepacol]. Ortodontia. 1990; 23(3):35-47.

5. Costa AC, Fernandes BC, Fonte PP, Gusmão ES, Santos RL, Silveira RCJ. Avaliação clínica de diferentes anti-sépticos bucais na redução do grau de gengivite em pacientes portadores de aparelho ortodôntico fixo 
[Clinical evaluation of different oral antiseptics in reducing the degree of gingivitis in fixed orthodontic appliance patients]. Rev Dent Press Ortodon Ortopedi Facial. 2004; 9(1):33-8.

6. Lascala CE, Belluzzo RHL, Lascala NT Jr. Procedimentos de motivação e higiene bucal em pacientes sob tratamento ortodôntico objetivando a saúde periodontal. Periodontia. 1996; 5(4):324-7.

7. Matos MS, Vianna MIP, Pitta A. Controle químico e mecânico de placa em pacientes ortodônticos. Uma análise por grupo de dentes de acordo com o acessório ortodôntico empregado [Chemical and mechanical plaque control in orthodontic patients. An analysis by group of teeth according to the orthodontic accessory employed]. Rev Dent Press Ortodon Ortopedi Facial. 2003; 8(1):87-93.

8. Neves S, Cruz RA. Aplicação de método de higiene bucal em pacientes portadores de aparelho ortodôntico. Rev Bras Odont. 1987; 44(4):2-8.

9. Löe $H$. The gingival index, the plaque index and the retention index systems. J Periodontol. 1967; 38(6):Suppl:610-6.

10. Rezende CLRD, Soares MF, Pereira CV, Oliveira G Jr. Influência da aparatologia ortodôntica na colonização microbiana das superfícies dentárias [Influence of orthodontic apparatology in the microorganisms' colonization on the teeth's surface]. Rev Dent Press Ortodon Ortoped Facial. 2001; 6(2):71-8.

11. Ristic M, Vlahovic Svabic M, Sasic M, Zelic O. Clinical and microbiological effects of fixed orthodontic appliances on periodontal tissues in adolescents. Orthod Craniofac Res. 2007; 10(4):187-95.

12. Heintze SD. A profilaxia individual em pacientes com aparelhos fixos: recomendações para o consultório [Individual prophylaxis in patients with fixed appliances: recommendations for the practitioner]. Ortodontia. 1996; 29(2):4-15.

13. Garib DG, Ungaro AE, Henriques JFC, Bastos JRM. Efeito do uso do gluconato de clorexidina e do cloreto de cetilpiridínio, em bochechos, como meio complementar da higiene bucal em pacientes sob tratamento ortodôntico [Efficacy of mouthrinses with chlorohexidine and cetylpyridinium chloride solutions, as complementary hygiene method in patients submitted to orthodontic treatment]. Ortodontia. 1997; 30(2):22-30.
14. Stefani CM, Lima AFM. Avaliação dos efeitos clínicos da aplicação de gel de clorexidina em pacientes sob tratamento ortodôntico. Rev Periodontia. 1996; 5:300-5.

15. Brecx M, Brownstone E, MacDonald L, Gelskey S, Cheang M. Efficacy of Listerine, Meridol and chlorhexidine mouthrinses as supplements to regular tooth cleaning measures. J Clin Periodontol. 1992; 19(3):202-7.

16. Charles $\mathrm{CH}$, Mostler KM, Bartels LL, Mankodi SM. Comparative antiplaque and antigingivitis effectiveness of a chlorhexidine and an essential oil mouthrinse: 6 -month clinical trial. J Clin Periodontol. 2004; 31(10):878-84.

17. Overholser CD, Meiller TF, DePaola LG, Minah GE, Niehaus C. Comparative effects of 2 chemotherapeutic mouthrinses on the development of supragingival dental plaque and gingivitis. J Clin Periodontol. 1990; 17(8):575-9.

18. Sekiguchi RT, Feng HS, Pannuti CM, Lotufo RFM. A clorexidina como coadjuvante no controle do biofilme dental durante o tratamento ortodôntico. Ortodontia. 2006; 39:166-9.

19. Bauroth $\mathrm{K}$, Charles $\mathrm{CH}$, Mankodi SM, Simmons K, Zhao Q, Kumar LD. The efficacy of an essential oil antiseptic mouthrinse vs. dental floss in controlling interproximal gingivitis: a comparative study. J Am Dent Assoc. 2003; 134(3):359-65.

20. Charles $\mathrm{CH}$, Sharma NC, Galustians HJ, Qaqish J, McGuire JA, Vincent JW. Comparative efficacy of an antiseptic mouthrinse and an antiplaque/antigingivitis dentifrice. A six-month clinical trial. J Am Dent Assoc. 2001; 132(5):670-5.

21. Fine $D H$, Furgang $D$, Barnett ML, Drew C, Steinberg L, Charles $\mathrm{CH}$, Vincent JW. Effect of an essential oil-containing antiseptic mouthrinse on plaque and salivary Streptococcus mutans levels. J Clin Periodontol. 2000; 27(3):157-61.

22. Gordon JM, Lamster IB, Seiger MC. Efficacy of Listerine antiseptic in inhibiting the development of plaque and gingivitis. J Clin Periodontol. 1985; 12(8):697-704.

23. Pan P, Barnett ML, Coelho J, Brogdon $\mathrm{C}$, Finnegan MB. Determination of the in situ bactericidal activity of an essential oil mouthrinse using a vital stain method. J Clin Periodontol. 2000; 27(4):256-61. 
24. Riep BG, Bernimoulin JP, Barnett ML. Comparative antiplaque effectiveness of an essential oil and an amine fluoride/stannous fluoride mouthrinse. J Clin Periodontol. 1999; 26(3):164-8.

25. Sekino S, Ramberg P. The effect of a mouth rinse containing phenolic compounds on plaque formation and developing gingivitis. J Clin Periodontol. 2005; 32(10):1083-8.

26. Tufekci E, Casagrande ZA, Lindauer SJ, Fowler CE, Williams KT. Effectiveness of an essential oil mouthrinse in improving oral health in orthodontic patients. Angle Orthod. 2008; 78(2):294-8.

27. Silness J, Löe H. Periodontal disease in pregnancy. II. Correlation between oral hygiene and periodontal condition. Acta Odontol Scand. 1964; 22:121-35.

28. Löe H, Theilade E, Jensen SB. Experimental gingivitis in man. J Periodontol. 1965; 36: 177-87.

29. Sharma N, Charles CH, Lynch MC, Qaqish J, McGuire JA, Galustians JG, Kumar LD. Adjunctive benefit of an essential oil-containing mouthrinse in reducing plaque and gingivitis in patients who brush and floss regularly: a six-month study. J Am Dent Assoc. 2004; 135(4):496-504.

30. Santos A. Evidence-based control of plaque and gingivitis. J Clin Periodontol. 2003; 30 Suppl 5:13-6.

\section{About the Authors}

Karla Magalhães Alves, DDS, MSc (Corresponding Author)

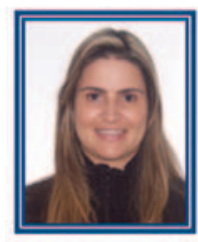

Dr. Alves has a Master's degree in pediatric dentistry from the Dental School of the Pontifícia Universidade Católica de Minas Gerais (PUC Minas), Belo Horizonte, MG, Brazil. Her areas of interest are pediatric dentistry and orthodontics.

\section{Daniela Goursand, DDS, MSc}

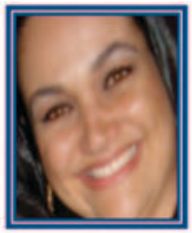

Dr. Goursand has a Master's degree and is a doctoral student in pediatric dentistry at the Dental School of the Universidade Federal de Minas Gerais (UFMG), Belo Horizonte, MG, Brazil. Her area of interest is pediatric dentistry.

e-mail: goursand@yahoo.com.br

Elton Gonçalves Zenóbio, DDS, MSc, PhD

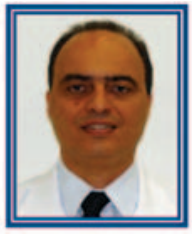

Dr. Zenóbio has a PhD in periodontics; and is adjunct professor in periodontics/dental implants at PUCMinas and coordinator of the Master's program in dental implants.

e-mail: zenóbio@pucminas.br

Roberval Almeida Cruz, DDS, MSc, PhD

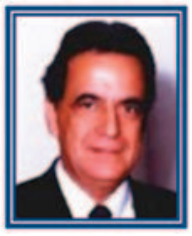

Dr. Cruz has a Master's degree in pediatric dentistry from the Universidade de São Paulo, Brazil, and a $\mathrm{PhD}$ in pediatric dentistry from the Universidade do Estado do Rio de Janeiro, Brazil.

e-mail: roberval@pucminas.br

e-mail: karlamaortodontia@ hotmail.com 